\title{
VIRTUES AND VICES ABOUT MONEY
}

\author{
Volker Kessler \\ Philosophy, Practical \& Systematic Theology \\ University of South Africa
}

\& Akademie für christliche Führungskräfte, Gummersbach, Germany

\begin{abstract}
According to the New Testament 'the love of money' is a root of all evil and a no-go for church elders. After the financial crises this warning and old virtues are rediscovered. The articles analyse virtues and vices dealing with money. Consulting insights from old texts such as Aristotle, the New Testament, Thomas Aquinas and modern authors like Comte-Sponville and Sofsky we develop a classification with two virtues, generosity and frugality, and two corresponding vices, meanness and greed. Due to the different facets of the topic we discuss these virtues and vices by combining explanations from philosophy, theology, psychology, sociology, and economy. These discussions are led by the question "how can we live these virtues in our modern society?". Especially, we discuss the challenge of living frugal in a market economy, which regards greed as a 'virtue in disguise'.
\end{abstract}

Key Words: Frugality, Generosity, Greed, Meanness, Virtue Ethics

\section{Introduction}

On 14 March 1997 an article in the German political magazine, Der Spiegel, claimed that "greed for money is good". On 13 February 2010 the front page of the same magazine read "The triumph of sin: about lust, greed and other temptations". Several financial crises occurred between the dates on which these two articles were written. The insight of the latest article is already found in 1 Timothy 6:10: "The love of money is the root of all kinds of evil" (HCSB). ${ }^{1}$ This verse continues with the warning that "by craving it, some have wandered away from the faith". This shows how seriously the love of money must be taken, as it can lead to a lapse from faith. Thus, love of money is an absolute no-go for church elders: they may not be 'lover[s] of money' (1 Tm 3:3), nor 'greedy for gain' ( $\mathrm{Tt}$ 1:7) and they must not fulfil their service as a shepherd 'for shameful gain' (1 Pt 5:2). Incidentally, this is the only requirement appearing in all three lists of criteria for the elders of a church (1 Tm 3:1-7; Tt 1:5-9; 1 Pt 5:1-3). ${ }^{2}$

Based on the claim that the love of money is a root of all evil, in this article I will examine which virtues and vices are especially related to money. This article is addressed to people who aim to live according to Christian ethics and especially to those Christians having leadership responsibility. The guiding question of the article is: "How can we live the virtues about money in our modern society?" In order to provide a solid answer to this question I will consult different disciplines such as philosophy, theology, psychology,

If there is no denotation of the translation used, I have used the English Standard Version (ESV). Other translations used were the Good News Bible (GNB-UK) and the Holman Christian Standard Bible (HCSB).

1Tm 3:1-7 lists 15 qualifications and Tt 1, 5-9 lists 16. In general, it can be stated that nine characteristics are identical, although the wording might differ slightly. These lists of qualifications obviously refer back to secular lists of virtues (Gielen 2001:303). 
sociology and economy. Classical as well as modern literature about virtue ethics will be taken into account. Being a Protestant theologian the Bible has a high authority for me. Thus theological ethics offers a framework in which I interpret other contributions. Especially, in the field of virtue ethics there is a great tradition from which Christians have always learned.

Before I start to discuss the virtues about money I would like to clarify my position concerning the relation between the Aristotelian view on ethics and the Biblical view on ethics (as I see it as a Protestant theologian). Aristotle saw the achievement of virtue as a way to reach happiness (eudaimonia), which he regarded as the highest goal of human action (NE I 5, 1097b). He was also optimistic that any (free) man could acquire the virtues by practice. Protestant theology will not agree with this view. As Christians our highest goal is to be part of God's kingdom. And as a Protestant theologian I believe in the justification by faith. This means that we have to receive God's spirit first before we can start to live a holy life. I share Wright's view on virtue ethics as it is expressed in his book After you believe: "The practice and habit of virtue, in this sense, is all about learning in advance the language of God's new world" (Wright 2010:69).

We can draw down some of God's future into our present moment. The rationale for this is that in Jesus that future has already burst into our present time, so that in anticipating that which is to come, we are also implementing what has already taken place. This is the framework of thought which makes sense of the New Testament virtue ethics (Wright 2010:66).

As virtue ethics is mainly concerned with the individual (micro level), only business and economic ethics (macro level) will be touched on.

The reader will soon recognise that the author writes from the perspective of the European middle class. I just wish to note that I grew up in more difficult circumstances. During my childhood our family had many discussions on money, not because we had so much of it but because we needed it so much. Thus I know from personal experience that 'the love of money' is not only an issue for the rich and wealthy. It can be an issue for poor people as well.

\section{The Quadriga}

The four cardinal virtues play an essential role in the ethics of virtue, and are mentioned in this constellation for the first time by Plato (428/7-348/7 BC).

Table 1: The four cardinal virtues

\begin{tabular}{|l|l|l|l|l|}
\hline & English & Greek & Latin & German \\
\hline 1. & prudence & phronesis & Prudentia & Praktische Klugheit \\
\hline 2. & justice & dikaiosyne & Iustitia & Gerechtigkeit \\
\hline 3. & fortitude & andreia & Fortitudo & Tapferkeit/Mut \\
\hline 4. & temperance & sophrosyne & Temperantia & Besonnenheit \\
\hline
\end{tabular}

"The word 'cardinal' means a hinge and these four virtues were thought to be the hinges upon which other virtues swing" (Kretzschmar 2009:27). They 'play a pivotal role' (Catechism 1993:par 1805). And precisely these four virtues are also praised by Wisdom of Solomon 8:7: "And if a man loves justice: her labours have great virtues: for she teacheth temperance, and prudence, and justice, and fortitude, which are such things as men can have nothing more profitable in life." 
These four virtues had an outstanding position in Greek and Roman moral philosophy (Plato, Aristotle, and the Stoics Cicero and Seneca), as well as in the ethics of the church fathers (Clement of Alexandria, Augustine). Thomas Aquinas, the famous teacher of the Middle Ages, offered a very systematic account of the virtues, giving them a clear hierarchy with prudence as the most important one, followed by justice, fortitude and temperance (STh II qu. 55-67). According to Aquinas (STh II qu. 62) the four human cardinal virtues are exceeded only by the divine virtues of faith, hope and love (1 Cor 13:13). The Catholic catechism (1993:par 1805, 1813) then lists exactly these seven virtues. Pieper's overview (2008) on the 'quadriga' (12) refers strongly to Aquinas's ideas.

Although the reformer Martin Luther was highly critical of Greek influence on Christianity, even he honoured the quadriga: "The four main virtues are distributed well: temperance keeps the body, justice nourishes, fortitude protects, and wisdom reigns" (translated from Aland 1983:233).

None of the cardinal virtues is exclusively about money, but this topic appears as an aspect of the virtues: equitable and appropriate payment, for example, is an aspect of justice. The Catholic catechism (1993:par 1807) makes a connection between the virtue of justice and Colossians 4:1, saying "Masters, treat your slaves justly and fairly, knowing that you also have a Master in heaven".

\section{Catalogues of Vices and Virtues in the Literature}

In the following, we will concentrate on the vices and virtues that refer specifically to money. To begin with, we will give an overview of the cases in which corresponding virtues appear in the catalogues. Such a selection can only be eclectic. We will refer especially to Aristotle's Nicomachean ethics, as well as to some modern publications, especially the catalogue of virtues by Comte-Sponville (2003) and the catalogue of vices by Sofsky (2009).

I regard Aristotle's Nicomachean ethics $(N E)$ as the best starting point for approaching the topic of virtues. The Nicomachean ethics are elaborate, practical and in many points surprisingly up to date. So the 'rearistotlization of ethics' (Höffe 1998:42) is extremely welcome. For Aristotle virtues are 'excellence of the soul' as opposed to 'excellence of the body' (NE I 13,1102a). Both are acquired by practice:

Hence it is incumbent on us to control the character of our activities, since on the quality of these depends the quality of our depositions. It is therefore not of small moment whether we are trained from childhood in one set of habits or another; on the contrary it is of very great, or rather of supreme, importance (NE II 1,1103b).

The structure of $N E$ is based on the understanding that the moral virtues can be destroyed by the deficiency of a certain virtue as well as the excess of it (NE II 1,1104a). This is the reason virtue always aims for the middle. Furthermore, the virtue prudence (phronesis) is assigned an important role: she has to find the middle between two extremes and decide for the best solution in the particular situation (NE II 5, 1107a).

Aristotle mentions 12 virtues (NE II 7,1107b-1108b), of which the third and fourth virtues deal explicitly with the topic of money: ${ }^{3}$

In regard to giving and getting money, the observance of the mean is Liberality; the excess and deficiency are Prodigality and Meanness, but the prodigal and the mean man exceed and fall short in opposite ways to one another: the prodigal exceeds in giving and

3 It could be assumed that dealing with money is also discussed under the headline "temperance" However, this is neither the case for Aristotle (NE 1118a-1119b), nor for Aquinas (STh II qu. 55-67; Pieper 2008:181-254). 
is deficient in getting, whereas the mean man exceeds in getting and is deficient in giving. (NE II 7,1107b)

In this regard, Aristotle is of the opinion that "right getting goes with right giving" (NE IV $2,1120 \mathrm{~b}$ ). He even invents a new virtue for exceptional liberality: magnificence (Höffe 1998:50): "the magnificent man being different from the liberal, as the former deals with large amounts and the latter with small ones" ( $N E$ II 7,1107b). Everyone can be liberal appropriate to his personal assets, but only the wealthy can be magnificent (NE IV 5, $1122 \mathrm{~b})$. According to Aristotle greed is a special case of injustice ( $N E \mathrm{~V} \mathrm{2}, 1129 \mathrm{~b}$; V 4, 1130a).

Table 2: Aristotle's virtues concerning money

\begin{tabular}{|l|l|l|}
\hline Deficiency & Virtue & Excess \\
\hline Meanness & 3. Liberality & Prodigality \\
\hline Paltriness & 4. Magnificence & Vulgarity \\
\hline Suffering injustice & 12. Justice & Being unfair (greed) \\
\hline
\end{tabular}

About 400 years later the New Testament provides another set of catalogues of vices and virtues. As mentioned above, the three catalogues of virtues for church elders (1 Tm 3:1-7; Tt 1:5-9; 1 Pt 5:1-3) all condemn the love of money as a vice. In Mark 7:20-23 12 vices are listed, which "All [...] come from within, and they defile a person". Greed is one of them.

Let us now look at some catalogues from the $20^{\text {th }}$ resp. $21^{\text {st }}$ century. The Italian-German Catholic philosopher Romano Guardini (1963) lists 17 virtues. However, none of them explicitly refer to money. Guardini only briefly mentions the whole subject of money, and this in the context of justice (1963:62).

André Comte-Sponville, an atheistic philosopher from France, lists 18 virtues in his "Short Treatise on the Great Virtues" (2003). One of these deals explicitly with money. Furthermore, he also talks about money in his interpretation of justice. Comte-Sponville is a strong observer of the ideas of Spinoza and Jankélévitch.

The Catholic liberation theologian Leonardo Boff (2009) from Brazil creates a new quadriga of virtues for the globalised world: "hospitality, community, tolerance, and table fellowship" (translated from Boff 2009:12). These virtues all touch the topic of money in their own way. For example part 3 is on the virtue of table fellowship and it contains a chapter "The bargain with starvation" (:265).

The German sociologist Wolfgang Sofsky (2009) lists 18 vices, of which three are concerned with money: greed, prodigality and meanness. Sofsky differentiates clearly: "Greed is a sin of taking, prodigality is a sin of giving, while meanness is a sin of having" (translated from Sofsky 2009:129).

\section{Virtues and Vices concerning Money}

I will deal with these virtues and vices according to the structure of table 3 . The virtues are sorted according to the actions: it is possible either to give money or to take money. This provides us with two virtues and two vices: not wanting to give and taking too much. In this scheme the vice is seen as the negation of the corresponding virtue. 
Table 3: Two virtues and two vices concerning money

\begin{tabular}{|l|lll|}
\hline Action & Virtue & $\leftrightarrow$ & Vice \\
Giving: & Generosity & $\leftrightarrow$ & Meanness \\
Taking: & Frugality & $\leftrightarrow$ & Greed \\
\hline
\end{tabular}

Let us compare this classification with the one of the Nicomachean Ethics. First of all, the structure of table 3 differs from Aristotle's scheme where two vices are assigned to each virtue: too much of it and too little of it. Furthermore, magnificence is not listed as a separate virtue because it can be seen as a special case of liberality, as Aristotle already pointed out ( $N E$ IV 4, 1122a). Aristotle assigns two vices to the virtue of liberality: meanness as deficiency and prodigality as excess. I would argue that prodigality can also be treated as a special case of greed, especially if we look at the today's consequences of prodigality. Every litre of fuel I use for driving my car is taken from the collective supplies of my fellow humans and my ancestors. Then prodigality becomes a special case of greed in the sense of wanting more than you are entitled to.

If we see greed as an individual vice and not as a special case of injustice (like Aristotle), the question arises what the corresponding virtue would be. I have chosen to call this vice 'frugality' (or contentment) as it is described in 1 Timothy 6:8, "But if we have food and clothing, with these we will be content."

As Aristotle (NE IV 1, 1120a) states: "Also it is easier not to take than to give: men are more reluctant to give away what belongs to them than to refrain from taking what belongs to someone else." There are people who are not greedy for more riches, but are mean about the belongings they have already attained. Actually, I have the impression that within the Western Christian community meanness is more common than greed. I know many Christians who cannot be accused of being greedy, since they never yearn for more. But they are not willing to share those things already belonging to them.

However, the languages do not always differentiate between meanness and greed. Aristotle used the word aneleutheria for 'meanness' (NE IV 1-3) and the word pleonexia for 'greed', the direct translation being 'wanting more' ( $N E \mathrm{~V} \mathrm{2;4).} \mathrm{The} \mathrm{second} \mathrm{one,}$ pleonexia, appears in several Bible verses (e.g. Lk 12:15, Eph 5:3, Col 3:5 et al.). In most cases it refers to greed but, like in 2 Corinthians 9:5, it is also used for meanness. The word aneleutheria does not appear at all in the Greek New Testament. 1 Timothy 6:10 and Hebrews 13:5 use the word philargyria, which literally means: 'love of silver/money'. People love their money so much that they do not want to give it away.

The Latin word avaritia and the English word avarice, which is one of the seven main vices according to the Catholic Church (Catechism par. 1866), can be used both for meanness and for greed. In the German language you have to decide between Habsucht (greed) or Geiz (meanness). ${ }^{4}$ The German Catechism (par. 1866) opted for Habsucht (greed).

I distinguish 'meanness' and 'greed' according to Sofsky (2009:129): greed is a sin of taking and meanness is a sin of keeping (as in 'not wanting to give away'). The greedy person wants to have more than is good for him, while the mean person wants to keep too much of what he has.

\footnotetext{
4 But it should also be noted that the German word Geiz (meanness) has its origin in the Middle High German gitte] with the translation being "greed".
} 


\section{Meanness and Generosity}

\section{The Vice Meanness}

The vice 'meanness' is judged harshly: "Meanness is an ugly sin. It makes man small and bitter" (translated from Sofsky 2009:128). Aristotle is similarly radical. While he remains optimistic concerning the prodigal - "but if he is taken in hand, he may attain the due mean and the right scale of liberality" - all hope seems lost for the mean: "Meanness on the contrary is incurable" ( $N E$ IV 3, 1121b). This decisive hopelessness is surprising, as Aristotle wrote his ethics in order to train humans for a better way (NE II 2, 1103b). Maybe, the radical wording concerning meanness should encourage the reader to train the virtue of generosity as early as possible. Aristotle recommends practising all of the virtues from a young age ( $N E$ II $1,1103 \mathrm{~b}$ ), but this recommendation seems to be especially important for this virtue. The reason is that some of the vices seem to decrease with age, while meanness unfortunately increases ( $N E$ IV 3, 1121b).

In most cases, a mean person is also mean towards himself. He does not allow himself any kind of pleasure. "He guards his treasures without even thinking about putting them to use" (translated from Sofsky 2009:129) ${ }^{5}$ and by this punishes himself, just as Jesus Sirach noticed: "No one is meaner than the man who is grudging to himself, and this is the retribution for his baseness" (Sirach 14:6, RSV). Should the mean man (have to) eat out, he will always "read the menu from right to left" (i.e. he will first look at the price), ordering the cheapest item on the menu, and complaining the most in the end. The fact that he is destroying the meal for the people around means nothing to him, for "meanness eats away the social senses" (translated from Sofsky 2009:132).

What makes the vice of meanness so complicated is the fact that it is very close to austerity, which some people would call a virtue. The mean person will now perceive his vice (in the view of those around him) as a virtue: he calls himself the virtuous money saver, while he views the people around him as prodigal. According to Max Weber the economical mind of Calvinism is the reason for the general success of Protestant countries over Catholic countries. Whoever teaches austerity as virtue is also teaching it as the opposite of the vice of prodigality. But is austerity a virtue at all? Aristotle does not mention it. His virtue corresponding with the vice of prodigy was not austerity, but liberality. Höffe (1998:47) calls austerity a 'secondary virtue'. Secondary virtues like orderliness are not good in themselves, but are dependent on what they are utilised for.

In a way, business economics cultivates the vice of meanness. Bookkeeping and accounting, cost savings by rationalisation, and efficiency control are all means of organising austerity which can easily become meanness. "Meanness in buying and greed in selling - this is the silver bullet of a rationalised economy" (translated from Sofsky 2009:137). It is unfortunate that people use their economic skills in fields in which they are completely inappropriate. I know the father of a family who calculated precisely whether another child would be a financial gain to the family, and who actually made the decision concerning another child dependent on the outcome of his calculations.

5 "The sinners of having and the sinners of meanness are direct opponents.... The prodigal and the mean share disrespect for items. What the one squanders immediately is only important for the other because it belongs to him. In the fourth circle of Hell they will meet, those who saved poorly and those who gave poorly" (translated from Sofsky 2009:139).

6 This is a saying within cultures where the menu lists the prices of the meals in the right column. 


\section{The Virtue of Generosity}

As explained above we will combine generosity and magnanimity. We will also concur with the definition provided by Comte-Sponville:

Generosity is the virtue of giving. But unlike justice, which requires that we give "to every man his own," to use Spinoza's definition, generosity entails giving the other person what is not his but yours, which he lacks. ... "One must be just before one can be generous"... (Comte-Sponville 2003:86). ${ }^{7}$

Comte-Sponville (2003:93) notes that "this virtue is hardly mentioned in the Christian tradition, for example in Augustine or Aquinas". This is a pity, especially given the fact that this virtue is taught in the New Testament. Paul, for example, gives the Corinthians clear instructions to support the Church in Jerusalem by collecting money when he writes: "Your abundance at the present time should supply their need, so that their abundance may supply your need, that there may be fairness" ( 2 Cor 8:14). And in Philippians 4:18 the apostle praises the generosity of the congregation in Philippi with the following words: "I have received full payment, and more. I am well supplied, having received from Epaphroditus the gifts you sent, a fragrant offering, a sacrifice acceptable and pleasing to God."

But Comte-Sponville (2003:88) would not even interpret such a collection as generosity, but as solidarity within a community of interests or a community with a common destiny. Solidarity within a community of interests is not seen as a virtue but as group egoism, which may be good and justified, but does not qualify as a virtue.

Comte-Sponville assumes that generosity is a virtue seldom put to use: "In short, I suspect generosity is so great and vaunted a virtue simply because we are so lacking in it, because our selfishness always wins out, because generosity is usually conspicuous by its absence" (2003:92). In order to evaluate your own generosity, Comte-Sponville (2003:91) recommends that the reader asks the crucial question "What percentage of your income do you devote to helping those who are poorer or less fortunate than you?" Comte-Sponville expects very low numbers:

What percentage of your household income ... contribute[s] to the happiness of persons other than yourself or those close to you? ... My guess is that nearly all of us contribute less than 10 percent and, more often, less than 1 percen. (2003:91-92).

If Comte-Sponville's estimation is valid, Christians who orient themselves according to the tithe are relatively exemplary, and would be much more generous than the average citizen. However, it must be stated that according to Comte-Sponville, giving within one community of interests is not actually liberality (see above). In the Bible this is seen differently. In Galatians 6:10 we are requested to "do good to everyone, and especially to those who are of the household of faith". We should give to everyone, and especially our suffering brothers and sisters in Christ, but not only to these people. Taking these considerations into account, we as Christians can let Comte-Sponville challenge us with his question: What percentage of our income actually goes to people outside of our religious community? I believe that in this case the estimation of less than $1 \%$ is probably realistic.

Comte-Sponville (2003:93) compares his classification with the Aristotelian one: "Generosity, then, appears to be at the crossroads of two Greek virtues, magnanimity and liberality". The corresponding endnote no.7 (:304) refers to Aristotle's section on liberality (NE IV 1-3) and magnificence (NE IV 7-9). I think that the term, generosity, in his classification is closer to Aristotle's idea of liberality because the Aristotelian magnificence only applies to wealthy people (NE IV 5). 
Comte-Sponville recognises generosity as a means of putting the commandment of charity into practice. As love cannot be measured, ${ }^{8}$ it is better to command precise deeds, such as generosity, for "love is the goal, generosity the road to it" (:101). This line of argumentation is similar to the one found in the letter of James: How can someone claim to love his brothers and sisters, if he does not help someone in need (Ja 2:15,16)?

\section{How to Obtain the Virtue of Generosity}

The example of generosity shows the charms of virtue ethics over other ethical approaches. Doing good is often perceived as an obligation or a sacrifice that we have to do against our disposition. This sense of sacrifice is especially common when it comes to practising the virtue of generosity, which is also manifested in the idea of the financial sacrifice when collecting money in churches. When I am generous, I give someone something that I will then not have any more. I will inevitably lose something which is not necessarily the case when I practise the virtue of fortitude (although it might happen when I help somebody who is in danger).

The interpretation of good deeds as a sacrifice is underlined by duty ethics, such as the idea of Immanuel Kant. According to Kant a deed you enjoy cannot be classified as moral behaviour. The virtue-ethical approach is very different, as MacIntyre (2008:149) emphasises: "To act virtuously is not, as Kant was later to think, to act against inclination; it is to act from inclination formed by the cultivation of the virtues." Aristotle does not see virtuous behaviour as a burden or an inconvenient duty, but as a pleasure and this is especially emphasised when discussing the virtue of generosity/liberality:

Liberality then being the observance of the mean in the giving and getting of wealth, the liberal man will not only give and spend the right amounts on the right objects alike in small matters and in great, and feel pleasure in so doing (NE IV 2, 1120b; my italics).

This corresponds with the New Testament ideal of a cheerful giver: "Each one must give as he has decided in his heart, not reluctantly or under compulsion, for God loves a cheerful giver" (2 Cor 9:7). The truly virtuous person gives freely and does good cheerfully. Or as the Catholic catechism (par 1810) puts it "the virtuous man is happy to practise them."

Of course, Aristotle knows that human beings are not generous from birth and that virtues have to be learnt and practised:

In fact pleasures and pains are the things with which moral virtue is concerned. For pleasure causes us to do base actions and pain causes us to abstain from doing noble actions. Hence the importance, as Plato points out, of having been definitely trained from childhood to like and dislike the proper things; this is what good education means (NE II $2,1104 b)$.

For the person educated in such a manner, "virtuous action is pleasant" or at least free of reluctance (NE IV 2, 1120a). It is the sign of a mature, virtuous person to feel virtue as pleasure. It is comparable to a husband in love for whom it is not a sacrifice to be true to his wife. In the best case he is happily true to her and does not even think of ever betraying her trust. In the same way, it is a great pleasure for the generous person to give.

8 I would like to point out that according to Comte-Sponville love cannot be commanded: "Love doesn't come on command, it can't be ordered up. Generosity is different: if we want to be generous, we can be" (2003:96). "In its own way, generosity, like most other virtues, obeys the biblical commandment. But can we really love our neighbor as ourselves? If we could, what would be the point of generosity? ... Only actions can be commanded; therefore the commandment requires not that we love but that we act as though we loved" (2003:97). 
What does this imply for us today? Firstly, the tithe is a good means of orientation, although formally it belongs to the old covenant and technically does not hold for the Christians today. It has the advantages of taking into account the different levels of income and being very precise. Furthermore, we should teach children from an early age to enjoy giving to others and sharing. The earlier children see how enjoyable it is to give to others in their families and churches, the better. This is the reason why we as parents have always advised our children to share a tenth of their pocket money. Since this act was supposed to be voluntary, we never checked up on them. In the light of accountancy this did not make any sense because their pocket money was already taken from our money of which the tithe had already been separated. Thus their pocket money was actually 'double-tithed'. However this situation was not about economics, but about education.

\section{Greed and Frugality The Vice of Greed}

Honestly, could our economics system even work without greed? In the film Wall Street from 1987 the character Gordon Gekko says the following words:

Greed - for lack of a better word - is good. Greed is right. Greed works, greed clarifies, cuts through, it captures the essence of the evolutionary spirit. ... Greed will - you mark my words - will not only save Teldar Paper, but the other malfunctioning corporation called the USA (in Balot 2001:20).

Although greed is considered unacceptable by the public today, do Gekko's words not show an inconvenient, but honest insight? Albach, a German professor for business economics, analyses the anthropology of his discipline:

Modern microeconomics assumes an individual that maximises his value. I should be clearer: modern microeconomics assumes an individual motivated by excessive greed as the normal case (translated from Albach 2003:37).

Market economy works under the assumption that people always want more. Without this urge to want more, there would be no economic growth. Without greed, a market economy simply would not work. Since the planned economy failed, the market economy is the only economic system that has survived. This means we need greed, at least in theory, for a functioning economic system.

Since this article is not a scientific elaboration on alternative economic systems, we will concentrate on the question of what each individual can do. How can greed be avoided? Here again Sofsky provides insightful thoughts:

Sometimes the greedy person suffers from a serious sort of hunting fever. The close fulfilment of his dream electrifies him. He wants to have his prey. His senses are sharp ... Any minute it can arrive, the rare chance that he has been awaiting for so long (translated from Sofsky 2009:121).

I assume that in selective moments many people know this hunting fever. You do not experience it when buying toothpaste or other everyday items, but whoever has been to an auction, has bought something on eBay or looked for a used car has experienced this hunting fever. Because every offer is unique, you are always in danger of missing the best opportunity, which is why you are under time pressure. "Greed is in a hurry. It prefers fast buying, fast auctions, and fast decisions" (:121).

Having this fever every once in a while may be controllable, for example when looking for a used car. It becomes a problem when this search for more becomes a principle of life. After a successful hunt, the fever is only satisfied for a short time. "As soon as the object is 
conquered, it loses its attraction" (:122). In conclusion, greed can never be fully satisfied. "Greed is insatiable. It knows no end. The collection is never full, nor is the bank account satisfactory" (122).

This insight can already be found in the Old Testament: "The one who loves money is never satisfied with money, and whoever loves wealth [is] never [satisfied] with income" (Eccl 5:10 HCSB). Furthermore, according to Matthews 6:24, "Jesus seems to regard Mammon as an enslaving force" (Van der Horst 1999:542).

The Frankfurter Zukunftsrat (Committee on the Future) underlines this with seven theses on neuroeconomics, a combination of neuroscience and economic science. Their second thesis reads: "The human reacts to short term profit or the prospect of money in the same way he does to cocaine" (translated from Frankfurter Zukunftsrat 2009). It has been measured that the same part of the brain is activated when people see money, gambling, chocolate or drugs. In the same way as the mind is deactivated when a drug addict sees drugs, so some people lose their minds over the prospect of high profits. This explains why much money is invested in products that, in hindsight (when the brain is back to full function), are clearly vulnerable and dishonest. If humans react to money in the same way as they do to drugs, it becomes obvious that greed is eventually addictive as well. This is also the third thesis of the Frankfurter Zukunftsrat.

I would, however, question one conclusion of the Frankfurter Zukunftsrat: they assume that the greed for money is hereditary. But Colossians 3:5 and Ephesians 5:5 clearly teach that 'greed is idolatry' (Rosner 2007). Thus greed violates the first commandment! That is something you have to take responsibility for. It is plausible that if you practise greed you can become addicted and not find your way out. Furthermore, it is plausible that people are different in their danger of being tempted. However, biblically it is impossible to get out of the responsibility by reasoning that greed is just a hereditary disposition.

Sofsky (2009) sees the vice of immoderateness as the escalation of greed. While the greedy person concentrates on a certain object, the immoderate is more interested in a great quantity $(: 145)$.

Unfortunately, in economics meanness as well as greed are practised with a perfected methodology, for example by setting objectives for the next term. No matter how well the previous year went, the new goal is always to increase profits in the next year. Why is that the case? Is it not possible to be content with the profit made as long as the necessities are dealt with, such as salaries, rent and interest? The complexity of the instruments leads to sophisticated objectives like 'increase of 3.54\%', concealing effectively that the base for this objective is not questionable. The business must grow and grow and grow.

The fact that the greed of rich countries, as well as the growing gap between rich and poor, is preventing peaceful community among rich and poor countries in this world is obvious (Boff 2009).

\section{The Virtue of Frugality}

Frugality or contentment is similar to the virtue of asceticism (Guardini 1963:98-107). However, they are not identical for asceticism also involves matters of the flesh, such as food intake or sexual drive. In this article, we are concerned with frugality concerning money and as the negation of the vice 'greed'. It is also mentioned in this context in 1 Timothy 6:6-8: "Now there is great gain in godliness with contentment, for we brought nothing into the world, and we cannot take anything out of the world. But if we have food and clothing, with these we will be content." The word autarkeia (contentment) used here was central in Stoic ethics. Frugality was seen as the embodiment of all virtues. Socrates, 
for example, is praised for having been so 'frugal and pious' (translated from Siede 1990:499). Obviously, 1 Timothy 6:6 is in line with Stoic ideas by connecting contentment and godliness. But it is also in line with other statements from the New Testament. Firstly, greed is idolatry (Col 3:5; Eph 5:5). Secondly, one cannot be a servant of God as well as of money (Mt 6:24; Lk 16:13). Thus being a Christian and being greedy do not fit together.

Paul characterises his own lifestyle in Philippians 4:11 as 'content'. The same word is used in Luke 3:14, in which John the Baptist encourages the soldiers to be "content with your wages" and not to extort money. And similar to 1 Timothy 6, Hebrews 13:5 teaches us to "[k]eep your life free from love of money, and be content with what you have".

A similar advice is already found in the Old Testament. On one hand the wealth of Abraham and Solomon are praised as a sign of godly blessing. On the other hand the words of Agur, son of Jakeh, describe the danger of richness: "give me neither poverty nor riches; feed me with the food that is needful for me, lest I be full and deny you and say, "Who is the Lord?' or lest I be poor and steal and profane the name of my God" (Prov 30:8-9).

Stoic as well as Biblical ethics request being content with the fate the Gods (Stoic) or Yahweh (Bible) has assigned to you, as long as the basic needs are met. Whoever lives with this attitude will not fall for the vice of greed.

What are the implications for us today? A remark concerning business practice: the theory of a market economy assumes that the price of an item results from the intercept point of the supply curve and the demand curve. This is true for products as well as salaries. As a result, a person who does not make the most of "what the market has to offer" (justification presented by a top manager in Germany for receiving an extremely high salary) is taken to be dumb. Assuming that as a supplier it is possible to request a price which is considerably higher than one's own costs - couldn't one still be content with only asking for enough to make sure the company remains safe (including investments in the future)? Interestingly, there are Christians who work according to the motto "I will take as much as I can so that I can donate as much as possible".

I know that our context is different from the NT context. Firstly, the words in 1 Timothy 6:8 are obviously directed towards private persons. Secondly, in the first century AD the price of items stood in direct relation to the manufacturing costs. In the modern business world this relation no longer applies in many fields. Thirdly, although Christian ethics does not provide us with exact rules for a 'Christian pricing', a Christian businessperson should not forget about 1 Timothy 6:8 while deciding on pricing. This is equally true for employees and their salary demands!

What does 1 Timothy 6:8 imply for a Christian as a private person? Basic needs vary from culture to culture and are dependent on climate, the prevailing average standard of living and the social class one belongs to. Beside officially defined basic needs, the individually felt needs can differ highly from one person to another. Whatever one feels is luxury (e.g. air conditioning in the car or having a car at all) might be the other's basic need.

It is interesting how the environment one lives in influences individual wishes. When I am in Germany, I have many wishes that become irrelevant when visiting a second- or third-world country. This lasts until about three months after returning from that country. Even missionaries and development workers, who live under the simplest conditions in a developing country and are very content with what they have there, are prone to like the amenities of their home country after their return. It is very human to adjust to the environment. 
It is often comparison with others that makes one unhappy with one's own situation. The neighbour's new car becomes a temptation because, solely by comparison, I notice how old my own car is. The tenth commandment deals with the wish to own something, which belongs to somebody else: "You shall not covet your neighbour's house; ... or his ox, or his donkey, ..." (Ex 20:17). We might add: your neighbour's car, his bank account, his retirement conditions etc. While other commandments refer to overt actions (do not kill, do not commit adultery, do not steal) ${ }^{9}$ the tenth commandment is directed towards the deepest inside of the human being: Do not covet. In other words: Be content with what you have.

Aristotle already pointed out that the virtues as well as the vices are interwoven. It is impossible to have no problems with one virtue, but to struggle with another. The vice 'envy' influences greed and the corresponding virtue 'frugality'. Often it is envy that prevents us from being content with the given. But envy is destructive (Haubl 2009). It is said that "jealousy eats you up inside". Envy is a sign of selfishness and by this the opposite of self-love. Violating the tenth commandment does the most harm to the violator.

Envy is often the result of an ideology of equality. The assumption that the opponent is better off financially leads to the feeling that wealth is distributed unequally and I am worse off than others. But that's life! Neither financial status nor traits like beauty, intelligence or talents are distributed equally, and it leads to self-destruction to live under the assumption of never having enough.

To be frugal means to be content with what you have received in an unfair world.

\section{Conclusion}

How then can we live virtuously? On the one hand, as Aristotle taught us, training, exercising the virtues, will help us to become more virtuous. On the other hand, our orientation needs to be 'above'. This is meant in the advice given in Colossians 3:3, when we are asked to "set your minds on things that are above" in combination with a warning about idolatry. And in Hebrews 13:5 we are motivated to be content, "for he has said, 'I will never leave you nor forsake you"'. God promises us a fulfilled life. Without the perspective of eternity, we are under enormous pressure to live life to the fullest while on earth. The perspective of eternity can prevent us from wanting to 'have it all' (greed) or to keep everything for ourselves (meanness).

\section{BIBLIOGRAPHY}

Aland, K (ed.) 1983. Luther Deutsch: Die Werke Martin Luthers in neuer Auswahl für die Gegenwart. Band 9 Tischreden. Göttingen: Vandenhoeck \& Ruprecht.

Albach, H 2003. Zurück zum ehrbaren Kaufmann: zur Ökonomie der Habgier. WZBMitteilungen 100 Juni:37-40.

Aristotle 1934 Nicomachean ethics, translated and edited by H Rackham. Available at: www.perseus.tufts.edu/hopper/text?doc=Perseus:text:1999.01.0054 (accessed on $5 / 5 / 2011)$.

Balot, RK 2001. Greed and injustice in classical Athens. Princeton: Princeton University Press.

9 These commands get an inward direction by Jesus's interpretation (Mt 5:28). 
Boff, L 2009. Tugenden für eine bessere Welt. Kevelaer: Butzon \& Bercker. Brazilian original. 2006. Virtudes para um mundo possivel. Petrópolis.

Catechism of the Catholic Church 1993. Available at: www.vatican.va/archive/ ENG0015/INDEX.HTM (accessed on 6/5/2011).

Comte-Sponville, A 2003. A short treatise on the great virtues. London: Vintage. French original: 1995. Petit traité des grandes virtues. Paris: Presses Universitaires de France.

Frankfurter Zukunftsrat 2009. 7 Thesen des Frankfurter Zukunftsrats zur Neuroökonomie. Available at: www.frankfurter-zukunftsrat.de/Presseservice/pdf/ pressemeldung20090617.pdf (accessed on 11/2/2010).

Gielen, M 2001. Tugendkataloge, in Lexikon für Theologie und Kirche 10:302-303.

Guardini, R 1963. Tugenden: Meditationen über Gestalten sittlichen Lebens. Würzburg: Werkbund.

Haubl, R 2009. Neidisch sind immer nur die anderen: uber die Unfähigkeit zufrieden zu sein. München: Beck.

Höffe, O 1998. Aristoteles' universalistische Tugendethik, in Tugendethik, edited by KP Rippe and P Schaber. Stuttgart: Philipp Reclam:42-68.

Kretzschmar, L 2009. Choose life, not death, in What is a good life? An introduction to Christian ethics in 21st century Africa, edited by L Kretzschmar, W Bentley and A van Niekerk. Kempton Park: AcadSA:11-41.

MacIntyre, A 2008. After virtue: a study in moral theory. 3rd edition. Notre Dame, IN: University of Notre Dame Press.

Pieper, J 2008. Über die Tugenden: Klugheit, Gerechtigkeit, Tapferkeit, Mass. (Vorwort v. Johannes Rau.) 2. Aufl. München: Kösel.

Rosner, BS 2007. Greed as idolatry: the origin of a Pauline metaphor. Grand Rapids: Eerdmans.

Siede, G 1990. Genügen, in Theologisches Begriffslexikon zum Neuen Testament. Studienausgabe Band 1:499-500.

Spiegel 2010. Available at: www.spiegel.de Archiv (accessed on 16.2.2010).

Sofsky, W 2009. Das Buch der Laster. München: Beck.

Thomas von Aquino. 1985. Summe der Theologie. Band 2. Die sittliche Weltordnung, edited by J Bernhart. Stuttgart: Kröner.

Van der Horst, PW 1999. Mammon, in Dictionary of deities and demons in the Bible, edited by K van der Toorn. 2nd edition. Leiden: Brill:542f.

Wright, NT 2010. After you believe: why Christian character matters. New York: HarperCollins Pub. 